\title{
Mallando nos Complementos directos: un ornitorrinco na sintaxe do galego
}

\author{
Teresa Moure \\ Universidade de Santiago de Compostela
}

\begin{abstract}
Resumo:
A gramática galega debe estimular a autenticidade da lingua e, en consecuencia, a súa sintaxe non pode reproducir punto por punto a do español. A sintaxe é a compoñente máis importante da gramática e por tanto tamén desde o ámbito sintáctico se debe procurar un galego vivo e fértil, con estruturas de seu, con usos diferenciados do español e, en definitiva, un galego de calidade. Neste sentido, os complementos directos con preposición do tipo de Comer no caldo constitúen un trazo diferencial co español que debe ser reintroducido nas nosas preferencias estilísticas.
\end{abstract}

\section{Palabras chave:}

Sintaxe, complemento directo, transitividade, lingua galega.

\begin{abstract}
:
The Galician grammar must stimulate the authenticity of the language and, consequently, its syntax cannot reproduce point by point the one of the Spanish. The syntax is the most important component of the grammar and so, from the syntactic scope, also alive and fertile Galician is due to look for, with its own structures and with uses differentiated well from the Spanish. To sum up, quality Galician must be preserved. In this sense, the direct complements with preposition, as it is the case of Comer no caldo, constitute a differential feature in relation to the Spanish that must be reintroduced in our stylistic preferences.
\end{abstract}

Key words:

Syntax, direct complement, transitivity, Galician language.

\section{Introdución: por que mallar nos complementos directos}

No momento actual, máis que noutro período histórico ningún, graves perigos afectan á nosa lingua, fundamentalmente a perda de falantes e a tendencia á ritualización nos usos. Neste contexto e ao longo de varias décadas, a práctica gramatical destinouse á recollida de datos (acusando, ás veces en exceso, o perfil dialectolóxico) e ás 
cuestións de normativización en sentido amplo: loitas ortográficas, negociacións normativas e decisións conducentes a un estándar. Ante a estrambótica situación de que, a cada máis, as persoas demostran boas actitudes cara á lingua mais non a falan, a gramática debe ocuparse tamén de reforzar unha idea que pode soar a purismo de especialista: a de estimularmos a calidade da lingua que manexamos. Pois ben, a nosa vida social está ateigada de textos e discursos cunha fonética aceptábel ou cun léxico ben escolmado e, no entanto, cuxa sintaxe reproduce punto por punto a do español. Considerarmos que as gramáticas de todas as linguas románicas están emparentadas até o punto de non se distinguiren parece un desatino: chamamos sintaxe ao conxunto de procedementos cos que codificamos as nosas mensaxes; as mensaxes poden ser universais, as codificacións que adoptan deben ser, por definición, máis particulares. Volvendo ao noso contorno, as gramáticas e as normativas céntranse en fonética e morfoloxía, tal que se os seus autores acreditasen que a sintaxe chegará como un engadido a eses compoñentes, ou simplemente, como se a sintaxe non fose un compoñente (na miña opinión o máis importante) da gramática. Algunhas voces veñen alzándose neste sentido para reclamaren unha lingua de calidade: querermos un galego vivo é tanto como procurarmos un galego fértil, con estruturas de seu, con usos diferenciais do español, que é a lingua que o ameaza. Esta tendencia foi defendida varias veces por investigadores, nomeadamente da Universidade da Coruña, os cales notan o uso do infinitivo flexionado, do futuro de subxuntivo ou do infinitivo xerundial, ou a delicadeza das transposicións na orde habitual dos pronomes (xa de por si dotada de regras complexas) como trazos definitorios do galego, como índices dunha sintaxe propia que se arma fronte ao avance e á intromisión das estruturas gramaticais do español ${ }^{1}$.

Nas páxinas que seguen quero someter a consideración os complementos directos con preposición, do tipo de Comer no caldo, Chamar pola nena ou Guindar coa pedra. Estou a me referir unicamente a aqueles casos en que a variante con preposición alterna coa forma habitual sen preposición, tal e como acontece nos exemplos anteriormente citados (onde as estruturas non preposicionais Comer o caldo, Chamar a nena e Guindar a pedra son perfectamente lexítimas e máis vitais actualmente que as primeiras). Os usos preposicionais foron pouco considerados na nosa tradición gramatical, que acusou as interpretacións circunstanciais (en particular a lectura locativa asociada á preposición en), sen incidir abondo en datos como:

(a) que esa preposición non é a única que aparece para introducir eses complementos e, cando está, perde, en todo ou en parte, o seu valor semántico,

1 Vid. Freixeiro Mato (2000) ou Sanmartín Rei (2007, 2009). 
(b) que estes complementos aparecen en toda a Galiza,

(c) que son máis abondosos na fala tradicional e popular que nos discursos cultos, e

(d) que aparecen preferentemente nas emisións dos falantes de maior idade, que moitas veces aínda notan que "así se falaba antes, non hoxe".

Estes factores convidarían a considerar eses complementos como un trazo diferencial co español que debe ser rescatado e reintroducido nas nosas preferencias estilísticas. De entrada, a escasa atención que recibiron na gramáticas pode ter a ver co feito de que estes usos preposicionais apenas se documenten en portugués. Porén resultan valiosos tanto polo seu carácter diferencial como por concordaren con principios de gramática universal. Neste sentido convén aclarar que o programa de investigación da tipoloxía lingüística vén estabelecendo nas últimas décadas hipóteses de amplo alcance, as cales, após se verificaren en moreas de linguas distintas, poden tomarse por universais estatísticos ou relativos. Porque, aínda que teñamos investido moito tempo en elixir a forma máis acaída para construírmos un estándar, cunha tradición gramatical tan sólida e ben alicerzada como a nosa, non debemos renunciar a fornecer con novas hipóteses unha teoría xeral sobre a linguaxe humana. Tamén desde a descrición do galego podemos facer teoría lingüística universal.

\section{Definindo o Complemento Directo}

A tradición gramatical define o complemento directo (en adiante CDIR) como o constituínte que designa a entidade afectada pola acción do verbo, do estilo dos segmentos destacados a continuación:

1a) Saleta cortou unha árbore

1b) Saleta regaloulle un libro ao seu irmán

Abofé que esta definición, por moi clásica que for, resulta insuficiente porque existen exemplares de CDIR que non designan entidades (como os da serie 2), ou que designan entidades non afectadas pola acción verbal (os de 3) ou que se ven involucrados en procesos verbais que non son accións (serie 4):

2a) Saleta sentiu a desolación que reinaba naquel lugar

2b) Saleta temperou os seus nervios

3a) Saleta abandonou a súa cidade natal

3b) Saleta perdeu o tren das dez 
4a) Saleta tiña frío
4b) Saleta esperaba que viñésedes

De non satisfaceren os requirimentos definitorios, poderiamos concluír que estes exemplares sintácticos non son CDIRs e rematar co asunto. Porén toda a tradición gramatical coincide en aceptalos como tales; daquela non fica outra posibilidade que recoñecer que a noción de CDIR debe ser definida moi coidadosamente, algo bastante inusual porque as funcións sintácticas nesta tradición recoñécense en vez de se definiren. Este aspecto metodolóxico é moi importante por canto contamos con precedentes de malas prácticas gramaticais, ben documentados, que conducen a resultados indesexábeis ${ }^{2}$. Tentaremos logo concederlle á noción de CDIR espazos máis amplos. En primeiro lugar, os segundos participantes de procesos do tipo acción poden non codificarse así:

\section{5a) Saleta berroulle ao seu irmán CIND}

5b) Saleta subiu ao tren CPREP

Mais nas linguas do mundo parece rexer unha forte tendencia a que os segundos participantes das construcións transitivas se codifiquen como CDIRs, isto é, como entidades estreitamente vinculadas ao predicado en caso de designaren entidades totalmente afectadas pola acción. Daquela, en Saleta cortou unha árbore, a árbore fica realmente afectada polo proceso, fica cortada, e a lingua exprésaa cun CDIR. En Saleta berroulle ao seu irmán, dificilmente os falantes conceptualizarán o irmán como unha entidade afectada pola acción: $o$ irmán só está involucrado nela posto que non fica "berrado". De aceptarmos este suposto, habería unha relación icónica entre a función semántica de paciente e a súa expresión na lingua: o CDIR sería a máscara sintáctica con que as linguas recobren o prototipo de paciente. Velaí que haxa unha diferenza sintáctica entre os exemplos das series 6 e 7 :

$\begin{array}{lll}\text { 6a) } & \text { Saleta montou o cabalo } & \text { CDIR } \\ \text { 6b) } & \text { Saleta montou a cabalo } & \text { CPREP } \\ \text { 7a) } & \text { Saleta pasou o río } & \text { CDIR } \\ \text { 7b) } & \text { Saleta pasou polo río } & \text { CPREP }\end{array}$

Nos exemplos das series (a) o falante actualiza no discurso unha entidade presentándoa como afectada polo estado de cousas que se describe: hai un cabalo particular e un río determinado dos que se predica algo. Nos exemplos das series

2 Vid. 5.2. a este respecto. 
(b), ao non se expresaren baixo aparencia de CDIRs, os participantes non se verán actualizados no discurso: en (6b) non hai un cabalo do mundo real, pode tratarse dunha posición corporal que adoptou Sabela (mesmo sobre outro obxecto ou ser distinto do cabalo); en (7b) o matiz é máis ben aspectual: o río puido non ser completamente cruzado, unha interpretación imposíbel para (7a). Segundo o principio da iconicidade propugnado pola gramática cognitiva de base funcional, a máscara sintáctica de CDIR xustifícase precisamente por esa máxima cohesión co verbo en todas as linguas do mundo. Coloco a seguir algúns exemplos:

$\begin{array}{llll}\text { ing.: } & \text { 8a) } & \text { John took the book } & \text { CDIRØ } \\ & \text { 8b) } & \text { John rode on the horse } & \text { CPREPon } \\ \text { fr.: } & 9 \text { a) } & \text { Jean a pris le livre } & \text { CDIR } \varnothing \\ & 9 b) & \text { Jean s'attache à son travail } & \text { CPREP } a ̀ \\ \text { esp.: } & \text { 10a) } & \text { Juan cogió el libro } & \text { CDIRØ } \\ & \text { 10b) } & \text { Juan habla de política } & \text { CPREPde }\end{array}$

Desde o punto de vista dunha gramática tipolóxica con vocación universal, o CDIR é nas linguas do mundo a expresión prototípica para o segundo actante da construción transitiva: unha entidade fisicamente discerníbel, que tende a interpretarse como paciente da actividade descrita polo estado de cousas e, xa que logo, directamente implicada no proceso. A súa intimidade co verbo perde deste modo a imprecisión que posuía na gramática tradicional para adquirir unha dimensión material, que se pode ligar ao seu carácter non-marcado, conformado nunha forma neutra.

\section{CDIRs preposicionais como complementos marcados}

Se hai que ir ás orixes, a teoría da marca é unha estratexia fonolóxica que a Escola de Praga desde os anos '30 introduciu nos estudos lingüísticos: a oposición vixente entre dúas unidades determinadas pode neutralizarse nalgún contexto, de xeito que só subsista a forma máis neutra, a non marcada, que nesa circunstancia particular representará tanto a presenza dunha propiedade como a súa ausencia. Con desigual fortuna esta teoría foi trasladada a diferentes estratos da lingüística. E se digo desigual fortuna é porque esta estratexia metodolóxica, moi útil nalgúns casos, serviu tamén para xustificar o sexismo na linguaxe, baixo o suposto de que o masculino, na súa suposta condición de forma neutra ou non marcada podería valer para denotar tamén o feminino, de xeito que $O$ home é un animal racional contería $O$ home é un animal racional + A muller é un animal racional posto que a oposición de xénero non 
estaría a rexer. Aquí a teoría da marca non pasa de ser un mecanismo con que soster a convención dos usos. Porén as súas aplicacións en sintaxe, como a que nos ocupa, son máis interesantes.

Desde esta perspectiva o CDIR marcado con preposición adquirirá algún valor non usual, de que estaría desprovista a forma non marcada. Mesmo é posíbel que a marca actúe de xeito escalar (Croft 1986): unha categoría lingüística mostra a súa realización menos marcada cando todos os seus atributos definitorios se cumpren en grao máximo; en ausencia dalgunha propiedade básica, a gramática salienta o carácter atípico dunha forma poñéndolle unha marca. En sintaxe poderiamos dicir que o CDIR non marcado aparece para dar a aparencia acaída a un segundo participante inanimado, definido e completamente afectado polo estado de cousas descrito polo verbo, o que é tanto como dicir para recubrir o paciente xenuíno. Pois ben, en galego, existen CDIRs marcados con preposición.

De entrada, ao igual que en portugués, catalán, español, engadino, sardo e romanés temos un CDIR marcado coa preposición $a$. Porén certos criterios prescritivos convídannos a consideralo na maior parte dos casos unha invasión do español e a eliminalo, de xeito que prefiramos Non hai que desprezar ninguén sobre Non hai que desprezar a ninguén ou Amo Xoana sobre Amo a Xoana, mesmo se os exemplos con $a$ están documentados na historia da lingua e aparecen en textos literarios de autoría prestixiosa. En todo caso, hai un aspecto que quero considerar. $\mathrm{Na}$ tradición gramatical do español, onde o CDIR con $a$ si se acha vigorosamente asentado, esta función sintáctica ofrece algunhas cuestións de interese. Detéñome momentaneamente nelas porque serán relevantes para o desenvolvemento posterior da miña argumentación.

En primeiro lugar, a presenza en español dun CDIR marcado con preposición adxudicouse a animación da entidade que serve como referente, de xeito que se diría escuchar ópera mais escuchar a alguien. Porén, chama a atención que ese CDIR preposicional produce en español unha confluencia entre un subconxunto caracterizado dos CDIRs e os CINDs. En (12a) a frase preposicional a su hermana actuaría como CIND, mentres que en (12b) actuaría como CDIR:

\section{Juan pegó a su hermana}

CIND

\section{Juan azotó a su hermana}

CDIR

Neste caso os gramáticos tiveron que fiar polo miúdo a súa argumentación: unha serie de complexas causas relativas á historia da lingua ou á estruturación gramatical (o "índice de non suxeito" que observa Alarcos en La tempestad sigue a la calma) explicarían una confluencia tan sorprendente. A explicación semántica non rexía 
sempre e, de feito, existen entidades humanas que se codifican sen preposición (13a), entidades abstractas que aparecen con ela (13b) e mesmo se dá o caso de que unha entidade humana poida codificarse con e sen preposicion (13c-d):

13a) El pediatra tomó el niño en brazos

CDIRØ(an)

13b) Los ciudadanos saludan al nuevo régimen calurosamente

$\operatorname{CDIR} a($ in, abst)

13c) Busco un criado

13d) Busco a un criado

Os dous últimos exemplos (13c-d) proceden dun gramático tan xenial e tan canónico como Andrés Bello, que reserva para (13c) a acepción de 'procurar alguén que faga oficio de criado' mentres a (13d) lle correspondería a de 'procurar alguén coñecido e determinado que fai oficio de criado'. O efecto non é exclusivo do español: Freixeiro Mato (2000: 635) nota idéntica posibilidade para o galego, e podemos documentar exemplos semellantes en hindú (apud G. Lazard 1984: 280):

$\begin{array}{lll}\text { hind. 14a) } & \begin{array}{l}\text { Mai naukar khojta hu } \\ \text { 'Busco un criado' }\end{array} & \text { CDIR } \\ \text { 14b) } & \begin{array}{l}\text { Mai naukar-ko khojta hu } \\ \text { 'Busco a un criado' }\end{array} & \text { CDIR-ko }\end{array}$

Precisamente, a aceptación na tradición gramatical do español de que a variación ausencia/presenza de $a$ non podía adxudicarse simplemente ao trazo semántico da animación propiciou unha serie de explicacións alternativas. Roegiest $(1979,1990)$ considerou a preposición $a$ coma unha marca da actividade potencial do obxecto, e Lazard (1984, 1985) comparou o CDIR con $a$ do español ao obxecto con posposición râ en persa. En todo caso a preposición, baleira de significado, non proporcionaría valores semánticos, senón que sería unha marca de certas alteracións sufridas polo esquema transitivo típico. Esta liña é a que quero explorar hoxe para o galego e os seus peculiares CDIRs con preposición distinta de $a$.

\section{A transitividade como propiedade non discreta}

Nun artigo xa convertido en clásico, dous autores norteamericanos da escola que se vén denominando funcionalismo tipolóxico, Paul Hopper e Sandra Thompson (1980), estabelecían para as linguas do mundo a relevancia da estrutura transitiva. Como as linguas humanas serven para a comunicación, a maioría dos esquemas gramaticais destínanse a contar o que acontece. Xa que logo, todas as linguas dispoñen 
dun esquema sintáctico básico para a expresión da transitividade, entendida como a transferencia de enerxía que vai desde un axente animado, que controla a acción, até un paciente inanimado, que a padece. O exemplo prototípico sería Saleta corta unha árbore, onde un axente animado protagoniza a acción de cortar, que é padecida por un obxecto inanimado, o cal fica altamente afectado polo estado de cousas descrito polo verbo (fica cortado). Segundo Hopper e Thompson (1980), todas as linguas teñen un esquema básico para relatar este tipo de acontecementos. Nótese que a transitividade nesta perspectiva é moi diferente á que tradicionalmente se usou en gramática. Nas visións frecuentes nos manuais, os verbos eran transitivos se ían acompañados de CDIR e intransitivos en caso contrario, de xeito que a transitividade se limitaba a unha cuestión de réxime verbal, un capricho construtivo. Nos exemplos da serie (15), amo constrúese con acusativo segundo os gramáticos latinos porque se desprende da súa natureza esixir un acusativo, e obsequor constrúese con dativo porque si, porque rexe dativo.

$\begin{array}{lllll}\text { lat.: 15a) } & \begin{array}{l}\text { Matr-em } \\ \text { nai-ACUS } \\ \text { 'Amo a miña nai' }\end{array} & \begin{array}{l}\text { me-am } \\ \text { miña-ACUS }\end{array} & \begin{array}{l}\text { amo } \\ \text { amo }\end{array} & \text { CDIR NON-MARCADO } \\ \text { 15b) } & \begin{array}{l}\text { Matr- } \boldsymbol{i} \\ \text { nai-DAT }\end{array} & \begin{array}{l}\text { me-ae } \\ \text { miña-DAT }\end{array} & \begin{array}{l}\text { obsequor } \\ \text { obedezo }\end{array} & \text { CDIR MARCADO } \\ & \text { 'Obedezo a miña nai' } & & \end{array}$

Na visión tipolóxica, que Hopper e Thompson probaron sobre unha manchea de linguas, a transitividade pasa a ser unha propiedade semántica e discursiva, regulada polas necesidades comunicativas dos falantes. Paréceme importante salientar neste sentido que o cambio de óptica converte a transitividade nunha propiedade emerxente, isto é, derivada da asociación de propiedades primitivas que ao operaren xuntas, adquiren novos atributos. Agora a transitividade supera a visión binaria tradicional para se converter nunha noción complexa, derivada de diferentes propiedades semánticas e discursivas e, o que aínda é máis notábel, susceptíbel de experimentar distintos estadios. En resumo, a transitividade é agora unha propiedade multifactorial, isto é, regulada por dez trazos que desenvolvo a seguir:

1. Dous participantes: un estado de cousas será máis transitivo de se ver expresado por dous participantes que no caso de se materializar a través dun só. Por iso a cláusula (16a) é máis transitiva que (16b):

16a) Saleta cortou unha árbore

16b) Saleta camiñou até se cansar. 
2. Acción: un estado de cousas será máis transitivo en caso de expresar unha acción que no de expresar un proceso. En consecuencia, (16a) é máis transitivo que (16c):

16a) Saleta cortou unha árbore

16b) Saleta sentía frío aquela mañá.

3. Aspecto: as predicacións onde a acción se desenvolva nun límite definido ou perfectivas transfírense con máis solvencia que as atélicas. De aí que (16a) sexa máis transitiva que (16c)

16a) Saleta cortou unha árbore

16c) Saleta está facendo a cea

4. Puntualidade: as actividades puntuais transfírense mellor que as que se desenvolven ao longo do tempo:

16a) Saleta cortou unha árbore

16d) Saleta pronunciaba o discurso de sempre

5. Volicionalidade: a transitividade é máis efectiva cando a acción enunciada polo estado de cousas aparece conscientemente controlada que cando isto non acontece. Por iso, de querermos notar que unha predicación non está baixo a responsabilidade do humano que a protagoniza, alteramos o esquema sintáctico co conseguinte descenso da transitividade
16a) Saleta rompeu o vaso
SUX- PRED-CDIR
16e) A Saleta rompeulle o vaso
CIND-PRED-SUX

6. Polaridade: As predicacións afirmativas indican que a transferencia efectivamente se produciu; as negativas están expresando que esa transferencia non tivo lugar. De aí que as primeiras tendan a se materializaren nas linguas do mundo con esquemas transitivos típicos e as segundas non. Aínda que esta propiedade non teña efecto en galego, si pode observarse en francés:

17a) Jean a mangé un gâteau

17b) Jean n'a pas mangé de gâteau

Os manuais escolares para a aprendizaxe do francés como segunda lingua defenden, con intereses didácticos, un absurdo paradigma de artigo indefinido: en frase 
afirmativa as formas son un, une, des ('un', 'unha', 'uns'/ 'unhas'), mentres que en frase negativa a única forma era $d e$. No entanto, desde a perspectiva que estamos asumindo, non precisamos un paradigma tan difícil de xustificar: a negación ten como efecto marcar a cláusula coa preposición de, que vén a marcar precisamente a súa atipicidade.

7. Modo real: o modo real indica que a transferencia foi/é/vai ser algo efectivamente producido, entrementres o irreal a presenta como algo pouco probábel, indesexábel ou inseguro:

16a) Saleta cortou unha árbore

16f) Non podo acreditar en que Saleta cortase a árbore.

8. Axentividade: A transitividade é sensíbel tamén ao tipo de causa que desencadea a acción. Un causante humano (16a) que controla o estado de cousas promove a interpretación transitiva:

\section{6a) Saleta cortou unha árbore \\ 16g) A porta bateu estrepitosamente}

9. Individuación: A transitividade benefíciase de obxectos ben individualizados. Por iso os nomes que se presentan como non individualizábeis acaban sendo analizados como predicados complexos, non como obxectos, ao estilo de ter présa, ter fame, ter sede. Obsérvese que podemos dicir Saleta ten televisión e non *Saleta ten saia mesmo se só ten unha. O asunto está en que unha sociedade determina que hai certas pertenzas que marcan status (ter mozo, ter coche, ter televisión) e outras non (*ter saia, *ter primo, *ter aparador). As primeiras convértense nun tipo de lexía complexa.

10. Afección do obxecto: a transferencia implícita na transitividade verifícase mellor sobre obxectos altamente concernidos pola acción e non sobre aqueles aos que o predicado só atinxe parcialmente:

18a) Saleta berrou unha consigna revolucionaria SUX-PRED-CDIR

18b) Saleta berroulle á policía SUX-PRED-CIND

Nesta liña, as linguas do mundo mostran diferentes alteracións do modelo prototípico transitivo: cando algún destes trazos definitorios da transitividade non aparece nunha emisión, a gramática da lingua correspondente marca esa emisión como atípica, se se quixer como anómala. En finés, o CDIR prototípico vai en caso acusativo. Mais os complementos directos que designan nomes masa, non individualizábeis, 
van en caso partitivo. Non se trata dun capricho construtivo do finés, senón dunha alteración sistemática (e preditíbel) do esquema transitivo prototípico, como se pode observar en 19(a-b), segundo exemplos de G. Lazard (1984: 274):

$\begin{array}{rlrl}\text { fin.: 19a) } & \begin{array}{l}\text { Juo }-n \\ \text { beber-eu } \\ \text { 'Bebo o leite' }\end{array} & \text { maido- } n & \text { CDIR PROTOTÍPICO } \\ \text { 19b) } & \begin{array}{lll}\text { Juo }-n \\ \text { beber-eu }\end{array} & \begin{array}{l}\text { maito- } a \\ \text { leite-PART }\end{array} & \text { CDIR NON-PROTOTÍPICO } \\ & \text { 'Bebo (algo de) leite' } & \end{array}$

Esta explicación é extensíbel aos datos do francés. Aínda que na tradición escolar estudaramos a existencia dun artigo partitivo obrigatoriamente aplicábel aos nomes masa, poderiamos pensar que o comportamento do francés en 20(a-b) non dista moito da explicación anteriormente aducida para o finés:

$\begin{array}{llr}\text { fr.: 20a) } & \begin{array}{l}\text { Je bois le lait } \\ \text { 'Bebo o leite' }\end{array} & \text { SUX-PRED-CDIR } \varnothing \\ \text { 20b) } & \begin{array}{l}\text { Je bois } \text { du lait } \\ \text { 'Bebo (algo de) leite' }\end{array} & \text { SUX-PRED-CPREP } d e\end{array}$

Máis un exemplo. En húngaro documéntase un obxecto en caso locativo por mor dun nome masa de acordo co exemplo de E. Moravcsik (1984: 57):

hun.: 21) A kenyérbe haraptam

'Como pan' [lit. 'Como no pan']

Chegados a este punto, as persoas galegofalantes recoñeceremos unha estrutura de noso: a alternancia Como pan e Como no pan pode ligarse aos valores semánticos e discursivos vinculados á transitividade. Porén volveremos a este punto máis tarde. Por agora rexistremos esta variante noutras linguas. En newari, unha lingua tibeto-birmana falada en Nepal, observamos dúas posibilidades alternativas para a construción. Cando a transitividade é prototípica, cun axente humano exercendo unha acción sobre un paciente inanimado, o esquema é o non marcado (neste caso, e dado que estamos ante unha lingua ergativa, co reparto de funcións ergativo-axente fronte a absolutivo-paciente). Cando algún trazo da transitividade prototípica non aparece, o esquema construtivo altérase cunha marca inesperada. Igual que en húngaro ou en galego, en newari aparece un locativo. Nos exemplos proporcionados por R. Langacker (1989: 233), o newari expresa co caso non marcado a acción 
prototipicamente transitiva e aplica o locativo á circunstancia en que o colchón sexa grande de máis para ser manipulado:

$\begin{array}{llll}\text { new.: 22a) } & \begin{array}{l}\text { wa-n } \\ \text { el-ERG } \\ \text { 'El bate o colchón' } \\ \text { 22b) wa-n }\end{array} & \begin{array}{l}\text { laasaa } \\ \text { colchón(ABS) }\end{array} & \begin{array}{l}\text { daala } \\ \text { bate }\end{array} \\ & & \begin{array}{l}\text { laasaa-e } \\ \text { el-ERG } \\ \text { 'El bate no colchón-LOC }\end{array} & \text { daala } \\ & & \text { bate }\end{array}$

Existen, obviamente, outras alteracións na codificación de CDIRs non prototípicos nas linguas do mundo mais non interesan agora porque chegamos ao punto desexado: talvez os nosos complementos con preposición poidan explicarse apelando a principios de sintaxe universal. Porque, de que outro modo poderiamos xustificar esta coincidencia na expresión? O húngaro, o newari e o galego non comparten unha orixe común. O húngaro é unha lingua da familia urálica, o newari da familia sinítica e o galego da familia indoeuropea. Tampouco non houbo procesos migratorios, nin unha convivencia entres as comunidades correspondentes que xustificasen o préstamo. Finalmente, agás neste punto, non hai coincidencias notábeis nas sintaxes correspondentes. Xa que logo, podemos estar ante unha restrición das que operan universalmente en gramática: as linguas humanas gardan entre si notábeis diferenzas mais non camiñan a valmontes, precisan vieiros determinados. Desde hai anos a tipoloxía lingüística fixa as restricións que operan para as linguas humanas coa idea de delimitar que é unha lingua humana posíbel.

Na oposición Comer no caldo / Comer o caldo a estrutura preposicional, a cada menos frecuente, ten un valor partitivo e aspectual diferente da estrutura non marcada. En Saleta comeu no caldo predico que, con toda probabilidade, Saleta estivo ocupada nesta acción mais non rematou a ración, algo que está implícito en Saleta comeu o caldo. O test de valor aspectual é sinxelo de facer:

- Se Saleta foi interrompida mentres comía no caldo, comeu no caldo? Si

- Se Saleta foi interrompida mentres comía o caldo, comeu o caldo?

Probabelmente non ou non todo.

Nótese ademais que a variante preposicional só xorde con verbos cuxa aktionsart implique certa prolongación no tempo: Ler no libro, Comer no caldo, Mallar nos complementos directos mais non *Ver nos nenos, *Dicir nestas palabras ou semellantes. Temos, pois, unha alteración nos trazos aspecto, puntualidade e afección do obxecto que, daquela, se nota cunha marca preposicional. Para os outros 
casos (Guindar coa pedra, Chamar pola nena), a hipótese non é tan forte ao non rexistrar variacións de aspecto: unicamente a menor afección do obxecto marca un complemento inesperado.

\section{As consecuencias de asumirmos unha gramática non discreta}

A tradición gramatical de que bebemos é unha tendencia de pensamento discreta, con solucións "de si ou non": un fonema é oclusivo ou non o é, decididamente, e unha función sintáctica será CDIR ou non o será, sen que caiban solucións intermedias. No entanto, sabemos que existen fonemas aproximantes, que relaxan algunhas das condicións requiridas para a oclusividade e que, no entanto, son en certa forma oclusivos. Igual que un pingüín ou unha aguia, por distintas razóns, non son paxaros prototípicos, mais resultan ser máis paxaros que réptiles, máis paxaros que mamíferos ou, en definitiva, máis paxaros que outra cousa ningunha. Desde hai anos vén desenvolvéndose en lingüística unha alternativa á categorización clásica que poderiamos denominar gramática non discreta (Moure 1996, 2001) coa que desenvolver as nosas teorías obre a linguaxe. En 1976 Keenan inauguraba esta tradición non discreta en sintaxe cun traballo sobre a condición non tallante do suxeito. Evidentemente, quen teña dado clases de gramática sabe que á hora de exemplificar perante un auditorio en galego debe de ser máis representativo do concepto de suxeito o segmento destacado en (23a) que o correspondente en (23b), malia os dous realizaren función de suxeito:

23a) Saleta cortou unha árbore

23b) Que dificil é prestar atención ás explicacións gramaticais!

De feito, Xoán é o suxeito típico que aducimos como exemplo nas aulas. Agora ben, na categorización discreta todo o debate estaba en decidir se un actante é ou non suxeito porque, unha vez dentro da categoría dos suxeitos, todos os exemplares teñen o mesmo status. Porén, nas categorías non discretas hai unha certa escalaridade, hai exemplares mellores e peores da categoría, igual que na clase dos homes altos é máis alto un individuo de 2,04 metros que outro de 1,96 aínda que ambos os dous poidan inserirse nela. A prototipicidade dos exemplares dunha categoría é unha cuestión complexa. De entrada, as funcións sintácticas non son entidades nítidas, perfectamente delineadas, senón territorios máis ou menos recoñecíbeis por un perfil definitorio que só os exemplares idóneos ou prototípicos ostentan precisamente por acumularen todas as propiedades definitorias da categoría. A condición de CDIR non é logo unha condición de "si ou non", senón que hai mellores e peores expoñentes desa categoría. En galego, por exemplo é idóneo o CDIR de Saleta cortou unha 
árbore e menos prototípico o CDIR de Saleta tiña présa: como no hai unha acción que se poida transferir nin un obxecto ben definido e afectado pola acción, é posíbel que os gramáticos analicen présa como CDIR mais serán sabedores de que non responde ben aos tests de detección:

24a) Saleta cortou unha árbore

-Pasivización: Unha árbore foi cortada por Saleta

-Substitución por clítico: Saleta cortouna

24b) Saleta tiña présa

-Pasivización: * Présa era tida por Saleta

-Substitución por clítico: * Saleta tíña

Para ver o efecto noutras linguas, en inglés, por exemplo, un CIND pode promocionarse á posición de CDIR cando se quere presentar como máis afectado pola acción. Mais non cumpre todas as propiedades do obxecto, non responde ás preguntas típicas nin pode relativizarse:

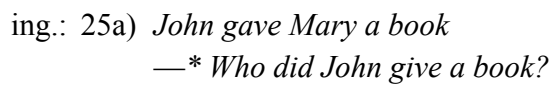

25b) John gave a book to Mary

—Who did John give a book to? / To whom did John give a book?

25c) John gave a book to the girl whose name is Mary

25d) * John gave the girl whose name is Mary a book

En consecuencia o CIND, ao se promover á posición de CDIR, pode participar dalgunhas características da clase máis nunca chega a ser un CDIR típico. Pois ben, boa parte das nosas estratexias lingüísticas (v. gr. a posibilidade de construírmos metáforas novas) relaciónase con esta posibilidade de se aproximar un membro periférico dunha categoría a outra diferente (igual que un pingüín pode ser, en certo xeito, paxaro).

Volvamos aos nosos exemplos. En galego podemos dicir Comer no caldo, Chamar pola nena ou Guindar coa pedra. Considero que estas tres construcións serían alternativas ao CDIR (CDIRs anómalos ou non prototípicos) e non ao Suplemento posto que de entrada poden darse as formas correspondentes con CDIR típico. Porén, Freixeiro Mato (2000) analiza estes casos como suplementos, igual que fixera Rodríguez Guerra (1997), quen mesmo apunta que "todos estes valores non funcionan como trazos distintivos desta estrutura”, senón que se deben circunscribir 
ao nivel "das realizacións substanciais". Non comprendo que se quere dicir con isto. De entrada, a división entre forma e substancia, procedente do primeiro estruturalismo (dos textos de Saussure ou Hjelmslev), é inusual nas aproximacións máis recentes aos estudos lingüísticos pola súa falta de rendibilidade e foi desbotada expresamente pola tipoloxía funcional. Mais, sen entrarmos en postulados deste tipo, como se pode dicir que é substancial (unha variante dunha invariante) sen traizoar os principios do estruturalismo? Porque, ao atoparmos unha diferenza de contido como é o aspecto, que se reflicte na expresión (co par ausencia/ presenza de preposición), non estamos ante un novo signo? Discrepo, pois, desta análise, sobre considerala ancorada nunha visión formalista dos feitos lingüísticos. Na liña anterior, Cidrás (1998: 570) fala destas preposicións como "produto resultante dun proceso medieval de emerxencia de distintas preposicións candidatas á gramaticalización no incipiente sistema de marcaxe diferencial do obxecto", o cal só as xustificaría diacronicamente, sen aclarar a súa funcionalidade.

Os CDIRs preposicionais do galego son o noso ornitorrinco. Como conta U. Eco (1997), para a bioloxía foi crucial o achado dun animal híbrido, descoñecido até que se explorou Australia, que viña a derrubar as clasificacións taxonómicas practicadas desde Linneo. O ornitorrinco é un mamífero atípico, con cola de castor e pico de pato; a femia aleita as crías aínda que non posúe propiamente mamas e conserva a antiga reprodución dos réptiles. A súa consideración de exemplar intermedio veu a derrubar moitas das categorías estabelecidas nas nosas disciplinas. Pois ben, os gramáticos do galego teimamos en colocar os CDIRs do tipo de Comer no caldo agora nunha categoría e agora noutra, sen decatármonos de que o relevante destes casos radica, precisamente, na súa propia condición intermedia.

Freixeiro Mato (2000) inclúeos no apartado do suplemento, salientando así o trazo formal da preposición. Na súa opinión a escolla entre Tirar o libro e Tirar co libro ou Comer as mazás e Comer nas mazás "non altera o significado léxico do verbo, aínda que si a semántica verbal, o aspecto, a maneira de se realizar a acción" (Freixeiro Mato 2000: 641). Na gramática de Álvarez, Regueira e Monteagudo (1986: 521), no entanto, non ficaba clara a súa natureza posto que indican estes autores ao respecto deste estilo de exemplos: "Hai casos en que o obxecto directo pode ir introducido por unha preposición distinta de $a$, e nestes casos chámaselle suplemento". Parecería que estes autores están a aceptar neste punto as etiquetas difundidas por eses anos desde as gramáticas do español mais na súa gramática non se volve recoñecer o suplemento, nin se menciona como apartado entre as funcións clausais. Álvarez e Xove (2002) adscríbenos ao CDIR a pesar de non cumpriren a maioría das características definitorias desa clase, en virtude da non rexencia da preposición por parte do verbo e aluden a "significados ligados ó complemento sobre o que se exerce a acción". 
Tanto os suplementos propiamente ditos (Falar de política, Xogar á pelota, Depender da túa vontade) como este tipo de segmentos preposicionais partillan algúns trazos que os distinguen dos CDIRs típicos.

a) Non admiten predicativos

26a) Pican a pedra miúda

26b) ? Pican na pedra miúda

b) Son dificilmente topicalizábeis

27a) A herba segueina

27b) *Na herba, seguei

c) Non poden pasivizar

28) *No caldo come Xoán

d) Substitúense por preposición + pronome tónico e non por clíticos pronominais

29a) Seguei a herba $\rightarrow$ Segueina

29b) Seguei na herba $\rightarrow$ Seguei nela

Como K. Veiga se encargou de demostrar nun traballo de investigación que foi realizado baixo a miña dirección e que se defendeu publicamente na Universidade de Santiago de Compostela mais aínda permanece inédito, os complementos do tipo de Comer no caldo teñen un comportamento idiosincrático. Con frecuencia arguméntase que CDIR e suplemento son funcións sintácticas distintas porque poden comparecer na mesma cláusula (Freixeiro Mato 2000: 640):

No entanto, non atopamos ningún caso en que CDIR e o CDIR preposicional comparezan xuntos. Por suposto, son complementos esenciais e non circunstanciais (contra toda posíbel interpretación locativa) posto que non se poden eliminar nin responden ao test con facer, deseñado para illar circunstanciais:

31a) Saleta comeu un bocadillo no xardín

CIRCUNS

-Saleta comeu un bocadillo

-Saleta comeu un bocadillo e fíxoo no xardín 
$31 b)$

Saleta comeu no caldo

-*Saleta comeu

-* Saleta comeu e fíxoo no caldo

31c) Saleta chamou pola nena

-*Saleta chamou

-*Saleta chamou e fíxoo pola nena

31d) Saleta guindou coa pedra

-*Saleta guindou

-* Saleta guindou e fíxoo coa pedra complemento esencial

complemento esencial

complemento esencial

Mais, a diferenza do que acontece cos suplementos, a preposición non está seleccionada polo predicado: mentres que en galego podo falar do significado de depender de ou xogar $a$, non podo falar dunha acepción comer en, guindar con ou chamar por.

Considero que hai dúas razóns fundamentais que xustifican estas vacilacións na análise, a saber, a azarosa historia da noción de complemento (5.1) e a excesiva importancia concedida na nosa tradición gramatical aos mecanismos de detección (5.2.).

\subsection{A dificultosa historia da noción de complemento}

A tradición gramatical anterior ao século XVIII é basicamente formalista. E non tanto pola vixencia dun programa de investigación como por puro azar histórico: unha serie de circunstancias externas converten o latín en centro da atención cultural por excelencia. Ao se tratar dunha lingua flexiva, a presenza de variantes morfolóxicas diferenciadas determina que a tarefa do gramático consista en rexistrar variacións de concordancia e réxime. O verbo amo esixe que o obxecto amado se exprese en acusativo mentres que obsum ('prexudicar') se acompaña regularmente dun dativo, sen máis explicacións. Só a partir da segunda metade do século XVII a moda lóxica bate na gramática francesa e reformula todo o aparato conceptual. O réxime perde daquela o carácter de condicionamento mecánico para se adaptar á noción de completude ou plenitude de sentido, co que inicia a súa paulatina transformación en complemento, un proceso que ocupa todo o século XVIII. A discordancia entre a variabilidade formal das linguas e a súa suposta identidade subxacente traza un corte brusco na análise que, dunha banda, atende os aspectos puramente gramaticais con etiquetas como nominativo ou acusativo e, doutra banda, ocúpase da lóxica referíndose a suxeito ou complemento. En adiante "directo" será o réxime que se vincule directamente ao verbo, "indirecto" o que reclame preposición. Deste xeito 
todos os complementos do galego actual exemplificados na serie (32b-d) serían catalogados, na gramática practicada nese período histórico, igualmente indirectos:

Sabela cortou unha árbore

Sabela deulles un regalo ás súas fillas Xoán chegou pola noite Dubidas da miña sinceridade
C DIRECTO

C INDIRECTO

C INDIRECTO

C INDIRECTO

A medida que o significado vai cobrando peso, esta perspectiva irá facéndose incómoda porque, nun exemplo como Vereite mañá, a ausencia de preposición levaría a analizar mañá como CDIR. Son precisamente os adverbios os que propician a introdución da etiqueta de circunstancial, a cal achegará novos problemas de recoñecemento porque a complementación dun verbo como saír se comporta de distinto xeito en (33a) e (33b):

\section{3a) Saleta saíu da casa $\rightarrow \quad$ Saleta saíu de alí \\ 33b) Saleta saíu de noite $\rightarrow \quad$ Saleta saíu daquela}

Por razóns semellantes as gramáticas escolares francesas estruturaran os complementos en dous niveis: no primeiro practícase unha diferenza semántica entre obxecto, ou complemento esencial, e circunstancial ou accesorio. No segundo clasifícase o obxecto en directo ou indirecto atendendo ao criterio formal de presenza/ausencia de preposición. Esta tipoloxía marcaría o panorama da gramática tradicional. É precisamente nun tal contexto que a gramática do español inicia unha dirección particular. Nela a importancia concedida aos criterios de detección acaba por identificar os complementos directo e indirecto coas posibilidades substitutorias das listaxes de clíticos pronominais. A práctica gramatical acaba por dispararse nesta tradición cunha auténtica proliferación de etiquetas: suplementos (nas súas distintas modalidades de suplemento propio, inherente, atributivo e indirecto), complementos adverbiais (locativos e modais) ou complementos directos adverbiais para os de medida, duración, peso e prezo son algunhas das divisións máis representativas. A gramática galega, probabelmente por cuestións de veciñanza e tamén porque os seus gramáticos se forman baixo o maxisterio de gramáticos do español, acaba por recoñecer a maioría destas funcións e faino acriticamente, sen cuestionar a adecuación dos procedementos usados no seu estabelecemento e sen darlle importancia aos ornitorrincos que aparezan na taxonomía.

Porque, por moi estritos que sexan os criterios para discriminalas, as funcións sintácticas resisten a unha categorización nítida e deixan entrever abondosas zonas de transición. 
PERCEPCIÓN DE VECIÑANZAS

$(+)$--trazos definitorios de $\mathrm{X} \rightarrow(-)$
NOVA FUNCIÓN SINTÁCTICA

$(+)$-- trazos definitorios de $\mathrm{X} \rightarrow(-)$

\section{$\leftarrow$ FUNCIÓN X -FUNCIÓN Y $\rightarrow \leftarrow$ FUNCIÓN X - FUNCIÓN Z - FUNCIÓN Y $\rightarrow$ \\ $(-) \leftarrow$ trazos definitorios de $\mathrm{Y}--(+) \quad(-) \leftarrow$ trazos definitorios de $\mathrm{Y}--(+)$}

A mellor proba desta veciñanza descóbrese en que as novas funcións sintácticas que se foron recoñecendo xurdiron do fracaso epistemolóxico. Os casos problemáticos non aparecen por torpeza dos gramáticos ou pola insuficiencia das súas teorías, senón por nos acharmos perante un espazo conceptual afectado dunha irresolúbel imprecisión. Mesmo o estruturalismo falaba de "zonas de contacto" entre funcións (Alarcos 1990) e só así pode valorarse a dificultade de estabelecer límites, por exemplo, en combinación cun mesmo predicado un participante altamente animado tende a interpretarse (v. gr. analizarse) como CIND; se a súa animación fose inferior, sería analizado como suplemento ou complemento adverbial:

34a) Xoán enfrontouse ao seu pai

CIND

-Xoán enfrontóuselle / *Xoán enfrontouse a el

34b) Xoán enfrontouse ás leis

SUPL

-*Xoán enfrontóuselles / Xoán enfrontouse a elas

35a) Xoán achegouse a María

-Xoan achegóuselle / *Xoán achegouse alí

35b) Xoán achegouse á xanela

-*Xoán achegóuselle / Xoán achegouse alí

Neste sentido, parece prometedora a vía adoptada por Heine, Claudi e Hünnemeyer (1991: 68):

[...] there is no continuity between categories like Object anda Space; indeed, many more intermediate entities could be identified if more contexts were considered. It is hoped that these few examples may suffice to give an impression of the continuum nature of the process from object to space or of any other categories. The conclusion to be drawn from such observations is that an analysis in terms of discrete metaphoral jumps captures only one aspect of the process.

Efectivamente, os nosos CDIRpreps serían entidades intermedias, algo que fica claro na súa condición de CDIRs non prototípicos. Deste xeito, practicariamos 
unha mesma análise para os casos do galego e os do húngaro ou o newari vistos máis arriba. Estabamos afeitos a que as categorías gramaticais estivesen compostas de exemplares idénticos e inmutábeis, de xeito que calquera forma distinta ou, simplemente, inesperada era marxinada no caixón das excepcións. Cando damos conta destas diferenzas sintácticas demostramos que as teorías están preparadas para construíren tamén unha sintaxe da variación, dos usos anómalos e desviados, e non só dos exemplares idealizados. Neste caso, a comparación interlingüística pode reducir unha serie de casos relegados pola tradición gramatical ao caixón das excepcións. Nin son tan excepcionais nin son varios os casos: trátase dun só fenómeno gramatical que pode explicarse unitariamente a pesar de materializarse con procedementos distintos nas linguas.

\subsection{A excesiva importancia concedida aos mecanismos de detección}

Unha función sintáctica é un concepto teórico da lingüística mais, na maioría dos casos, as funcións naceron vinculadas a necesidades prácticas de detección, sobre todo no ámbito académico. De aí que en distintas tradicións gramaticais, nomeadamente na hispánica, o papel dos mecanismos de detección estea inflado. O funcionalismo ovetense, con Alarcos como figura principal, consagraría como criterio definitorio do CDIR o que en Andrés Bello era un simple mecanismo identificador: a substitución por un pronome átono da serie acusativa. Daquela, algúns exemplares tradicionalmente incluídos nesa clase e que racionalmente non podían pertencer a outra, resultan excluídos: os candidatos a CDIR que non puidesen substituírse por lo e as súas variantes de xénero e número non serían verdadeiros CDIRs. O concepto de CDIR redúcese así perigosamente, porque a definición é axiomática e prescinde das restricións que rexen para o uso do clítico. De feito ese recurso non é viábel (tampouco en español) cando a entidade referencial a que se alude non está suficientemente individualizada. Compárese

36a) Xoán ten fame $\rightarrow$ ? Xoán tena

36b) Xoán ten iso que me pides $\rightarrow$ Xoán teno

37a) Xoán toma café (e non té) $\rightarrow$ ?Xoán tómao

37b) Xoán toma un café $\rightarrow$ Xoán tómao

Se fame ou café non responden á proba definitoria habería que concluír que non son verdadeiros CDIRs e consecuentemente habilitar unha nova clase para exemplares deste estilo. Estas dificultades sortéanse cun cambio terminolóxico. Alarcos acuña a noción de implemento e colócaa no lugar do tradicional CDIR. A partir de aquí toda crítica resulta improcedente: xa non se trata de que os constituíntes que se 
resistan a seren substituídos por pronome non sexan CDIRS, simplemente non son implementos por fracasaren ante o único criterio definitorio desta clase. O cambio terminolóxico salvagarda a teoría e evita posíbeis críticas externas mais non mellora a súa capacidade descritiva nin xustifica a substitución por clíticos como único criterio para definirmos unha función sintáctica. Fica pendente, entre outros desaxustes, a cuestión de catalogarmos os exemplares que, como os anteriores, remiten á clase do CDIR e que, no entanto, o implemento non recolle. Aínda que a postura máis congruente pasaría por habilitar unha nova etiqueta, ese paso nunca se deu.

Volvendo á nosa tradición, parece que os gramáticos tenden a valorar en exceso as probas de detección que nin sequera son tan definitorias en galego, onde o clítico ten un campo de uso máis reducido. O feito de nós podermos eliminar o CDIR tras unha pregunta sen deixar pegada no verbo, é indicativo dunhas diferenzas de comportamento co español que cuestionan moito o uso deste criterio como válido para illar funcións sintácticas fóra da lingua onde resultou estabelecido como tal:

38) Cortaches a árbore? Cortei / Corteina

Podemos habilitar procedementos de detección de funcións sintácticas útiles en maior ou menor medida mais unha función non é igual que un procedemento. Isto supón que calquera dos índices que usemos para recoñecer funcións sintácticas, nomeadamente con fins didácticos, pode fallar. É evidente que a substitución non funciona sempre e tamén que pode illar outras funcións sintácticas, como é o caso dos predicativos dos verbos atributivos. De aí que, á hora de analizarmos os complementos directos preposicionais non é a substitución a condición que debe decidir a súa inclusión ou non nesta clase: se quixermos ser moi coherentes coa substitución, hai que recoñecer que se verifica menos veces das que pensamos cando ideamos exemplos.

\subsection{As vantaxes dunha nova opción}

A categorización en lingüistica como en todas as ciencias en Occidente remite a unha tradición discreta. Esperamos que un conxunto de propiedades (a, b, c, d, e) delimite a clase dos vexetais fronte á dos animais. Idealmente, os exemplares da clase dos animais reunirían todos os atributos definitorios desa clase (a, b, c) e ningún dos da outra; mentres que os exemplares da clase dos vexetais coincidirían en non satisfaceren ningún dos trazos anteriores e, no entanto, cumprir os propios da súa categoría (os trazos d, e, por exemplo). Porén, na maioría das nosas categorizacións aparecen exemplares intermedios, que cumpren algúns dos trazos característicos de cada unha desas dúas clases enfrontadas. A gramática historicamente tendeu a silenciar eses casos problemáticos, que ameazaban a solidez 
das súas divisións. Nun momento posterior, decidiu sobre estas áreas rebeldes estabelecer novas clases intermedias. De atoparmos un virus ou unha estrela de mar, individuos que cumpren algúns dos requirimentos da clase dos animais e algúns da clase dos vexetais, podemos construír unha categoría intermedia. Este foi o proceder habitual na gramática do español que, ao longo das últimas décadas multiplica o seu aparato conceptual introducindo complementos directos adverbiais, complementos adverbiais locativos, complementos adverbiais modais, suplementos inherentes, aditamentos intermedios, suplementos propios, suplementos indirectos e suplementos atributivos, ademais dos máis tradicionais, complementos directos, complementos indirectos, circunstanciais, complementos axentes, predicativos e atributos nunha auténtica proliferación de funcións sintácticas.

Porén esta solución non é acaída: un virus e unha estrela de mar non son a mesma cousa: aínda que coincidan en ser entidades intermedias entre animais e vexetais, non conforman unha clase. Xustamente para evitar estes desaxustes, cómpre recoñecer outro tipo de clases, conxuntos non discretos, caracterizados por un foco (onde se verifican todos os trazos definitorios) e unha periferia menos definida. A consideración dos CDIRs preposicionais do galego como exemplares pouco típicos desta categoría (mais non como unha categoría de seu) corresponde a esta nova óptica que deitamos sobre a gramática e que pode verse en Rivas (2002), en Rodríguez Guerra (1997) ou en Moure (1999). No entanto, estes traballos non gozaron da fortuna de influíren sobre o panorama gramatical. Velaí a razón última destas páxinas.

En galego, como en todas as linguas, notamos discordancias entre os distintos CDIRs e isto só pode conducirnos a rachar con aquelas categorías inmutábeis: non todos os exemplares aglutinados baixo a denominación de CDIR son iguais porque existe un continuum de transitividade interlingüístico con demarcacións particulares nas distintas linguas. Por moi estritos que foren os criterios empregados para discriminalas, todas as funcións sintácticas se resisten a unha categorización nítida e mostran abondosas áreas intermedias. Cun tal perfil, os casos problemáticos ou anómalos non deben interpretarse como resultado de vacilacións teóricas nin da insuficiencia das nosas teorías, senón como espazos conceptuais afectados dunha irresolúbel imprecisión. Cada función sintáctica posúe un foco nítido, desde o cal os seus exemplares se diversifican, penetrando na área de influencia doutras funcións veciñas. Só así pode valorarse a dificultade de estabelecermos límites. Na gramática actual as hipóteses de contigüidade, ligadas a concepcións non discretas da realidade lingüística, son habituais. Como vantaxe primordial incorporan a posibilidade de relacionaren os distintos mecanismos con que se gramaticalizan valores semánticos como obxecto, dativo ou locativo. A aposta por hipóteses tan fecundas e orixinais é, ante todo, unha necesidade metodolóxica. 
Non dispoño actualmente de datos sobre a extensión destes complementos, simplemente teño a intuición, máis ou menos contrastada con preguntas informais a falantes solventes, de que o uso dos CDIRs con preposición entrou en franca decadencia ${ }^{3}$. Como tantas peculiaridades da fala tradicional, estes complementos son totalmente alleos aos máis novos e, no entanto, moi abondosos nas persoas de máis de sesenta anos. Gustaríame convocar desde aquí a unha investigación máis detallada sobre os CDIRs preposicionais. De acordo con hipóteses de gramática universal este CDIR é perfectamente viábel, ten unha explicación semántica e vitalidade comunicativa e a súa análise, nesta perspectiva, permite colocar o galego no lugar que debe estar, como unha máis das linguas do mundo, desde a que se poden construír hipóteses con validez non só para restaurar a forma de fala de noso, tamén para comprendermos (e comprenderen as demais tribos) como funciona a linguaxe e a mente humana. A escasa referencialidade do obxecto en Saleta colleu de chaqueta (fronte a Saleta colleu a chaqueta), a atelicidade de Saleta agardou por María (fronte a telicidade de Saleta agardou a María), ou a diminución da volicionalidade en Saleta tirou co vaso (fronte a Saleta tirou o vaso) son dabondo elocuentes como para non desbotar a hipótese da preposición servir a intereses comunicativos asociados á transitividade. Na miña opinión estes CDIRs preposicionais constitúen, daquela, máis un trazo característico da nosa sintaxe, no caso de que aínda sexamos quen de coidar neles.

\section{Bibliografía}

Alarcos Llorach, E. (1990): “La noción de Suplemento", Homenaje al prof. F. Marsá. Jornadas de filología: 209-221 (Barcelona: Univ. de Barcelona).

Álvarez, R. / Xove, X. (2002): Gramática da lingua galega (Vigo: Galaxia).

Alvarez, R., Regueira, X. L. / Monteagudo, H. (1998) [1986]: Gramática galega (Vigo: Galaxia).

Cidrás Escáneo, F. A. (1998): "Marcaxe preposicional de obxecto en galego. Emerxencia e vicisitudes dun proceso de gramaticalización sintáctica”, en Krener, D. (ed.), Homenaxe a Ramón Lorenzo: 569-580 (Vigo: Galaxia).

Croft, W. (1986): Categories and relations in syntax: the clause-level organization of information, Univ. microfilms internacional.

Eco, U. (1997): Kant e l'ornitorinco, Milano, RCS libri. Trad. esp. de H. Lozano, Kant y el ornitorrinco (Barcelona: Lumen).

3 Os datos escolmados máis polo miúdo que eu coñezo son os referidos por Rodríguez Guerra (1997): 
Freixeiro Mato, X. R. (2000): Gramática da lingua galega. II Morfosintaxe (Vigo: A Nosa Terra).

Heine, B., / Claudi, U. / Hünnemeyer, F. (1991): Grammaticalization. A conceptual framework, (Chicago: Univ. of Chicago Press).

Hopper, P. / Thompson, S. (1980): “Transitivity in grammar and discourse”, Language 56/2: 251-299.

Langacker, R. (1989): "Settings, participants, and grammatical relations", en Tsohatzidis, S. (ed.), Meanings and prototypes. Studies on linguistic categorization: 213-238 (London-New York: Routledge and Kegan Paul).

Lazard, G. (1984): “Actance variations and categories of the object", en Plank, F. (ed.): Objects. Towards a theory of gramatical relations: 269-292 (London: Academic Press).

Lazard, G. (1985): "A few remarks on actance gradients", en Seiler, H. \& Brettschneider, G. (eds.): Language invariants and mental operations. Internacional interdisciplinary Conference held at Gummersbach/Cologne, Germany, september 13-23, 1983: 245-247 (Tübingen: Gunter Narr Verlag).

Moravcsik, E. (1984): "The place of direct object amoung the noun phrase constituents of Hungarian", en F. Plank (ed.): Objects. Towards a theory of grammatical relations: 55-85 (London: Academic Press).

Moure, T. (1996): La alternativa no-discreta en lingüística. Una perspectiva histórica y metodológica (Santiago de Compostela: Univ. Santiago de Compostela).

Moure, T. (1999): “Aspectos da sintaxe do galego desde a perspectiva tipolóxica", en Álvarez, R. \& Vilavedra, D. (eds.): Cinguidos por unha arela común. Homenaxe ao prof. X. Alonso Montero, vol. 1: 751-766 (Santiago de Compostela: Univ. Santiago de Compostela).

Rivas, J. (2002): “Complementos directos periféricos”, en Lorenzo, R. (coord.): Homenaxe a F. Tato Plaza: 255-266 (Santiago de Compostela: Univ. de Santiago de Compostela).

Rodríguez Guerra, A. (1997): “Aspectos da transitividade galega: os complementos con 'en"”, en Fernández Salgado, B. (ed.): Actas do IV Congreso internacional de estudios galegos (Univ. de Oxford, 26-28 de setembro de 1994), vol 1: 343-352 (Oxford: Centro de Estudios galegos).

Roegiest, E. (1979): “À propos de l'accusative prépositionnel dans quelques langues romanes", Vox romanica 38: 37-54. 
Roegiest, E. (1990): “La tipología sintáctica del objeto transitivo en español”, Verba 17: 239-248.

Sanmartín Rei, G. (2009): Nos camiños do entusiasmo. Calidade da lingua e planificación (Vigo: Xerais).

Sanmartín Rei, G. (coord.), (2007): Criterios para uso da lingua (A Coruña: Servizo de Normalización lingüística da Univ. da Coruña).

Veiga, K. (2003): Iconicidade na linguaxe. Os complementos directos preposicionais do galego, TIT defendido na USC. 